\title{
Should We Teach the Impolite Language? A Study of Iranian EFL Learners, Teachers, Experts and Non-Iranian Experts' Attitudes
}

\author{
Alireza Ahmadi \\ Shiraz University, Shiraz, Iran \\ Email:ar.ahmadi@yahoo.com \\ Kamal Heydari Soureshjani \\ Islamic Azad University, Shahrekord Branch, Iran \\ Email: kamal.heidari@yahoo.com
}

\begin{abstract}
Unlike politeness which has greatly been studied by researchers, the impolite or rude language has mostly been neglected. The current study is an attempt to examine this neglected aspect of the language. The study has focused on whether the impoliteness aspect of language should be taught in an Iranian EFL context? To this purpose, four groups of participants, namely, language learners, language teachers, Iranian language experts, and non-Iranian language experts were surveyed for their ideas toward the impolite language. No significant difference was found in the ideas of the four groups concerning "the importance of impoliteness as compared to politeness", "the equal treatment of genders in teaching impoliteness", and also concerning "the context of teaching impoliteness". Significant results were; however, found in their ideas concerning "the general significance of impoliteness in everyday language", "teaching impoliteness in language classes", "methods of teaching impoliteness (direct vs indirect)", and "the level of proficiency required for teaching impoliteness".
\end{abstract}

Index Terms-impoliteness, Iranian experts, non-Iranian experts, EFL learners, EFL teachers

\section{INTRODUCTION}

Despite the fact that much attention has been paid to the politeness aspect of language, as a branch of pragmatics, its counterpart, impoliteness, has been mostly neglected. As Mugford (2008) states, English language teaching tends to deal with the pleasant side of language interaction such as making friends, relating experiences, and expressing likes/dislikes, while ignoring such everyday communicative realities as rudeness, disrespect, and impoliteness. However, it is a truism that in order to master a language, language learners are required to learn both the politeness and impoliteness aspects of the intended language. Impoliteness is part of everyday language use and language learners need to be prepared to interact in impolite situations or at least to be able to make a distinction between polite and impolite use of language. Moreover, according to Mugford (2008), language learners have the communicative right to be rude if they want to, as long as they are aware of the consequences of their actions. And to be able to do so, teachers need to take the lead by preparing learners to communicate in pleasant, not so pleasant, and even abusive interactional and transactional situations. Preparation involves helping learners identify potentially impolite practices and offering ways of dealing with impoliteness. Mugford also illuminates that teachers, by not teaching the impoliteness aspect of language, are potentially allowing language learners to be dominated by the target language users.

In earlier publications on interpersonal communication, impoliteness was either ignored or simply treated as a pragmatic failure to meet the politeness principles of talk (Leech, 1983). More recently, however, we find a growing tendency to categorize impoliteness as a "systematic" (Lakoff, 1989), "functional" (Beebe, 1995), "purposefully offensive" (Tracy and Tracy, 1998) and "intentionally gratuitous" (Bousfield, 2008) strategy designed to attack face. Among all proposed definitions by different researchers, though they are all reasonable and respectable, it seems that the definitions by Bousfield (2008) and Culpepper et. al (2003) have gained more popularity.

Bousfield (2008) defines impoliteness as constituting the issuing of intentionally gratuitous and conflictive facethreatening acts (FTAs) that are purposefully performed. Culpeper et al. (2003, P. 11) firstly defined impoliteness as "communicative strategies designed to attack face, and thereby cause social conflict and disharmony". Later on (2005, P. 38 ), in another study they defined this concept in a somewhat different and more comprehensible way:

Impoliteness comes about when: (1) the speaker communicates face-attack intentionally or (2) the hearer perceives and/or constructs behavior as intentionally face-attacking, or a combination of (1) and (2).

As it can be seen from these two definitions, Bousfield and Culpeper consider the hearer's understanding of the speaker's intentions as the key for impoliteness. One point with regard to Culpeper's definition made by Bousfield (2007) is that while it is laudable that Culpeper is attempting to incorporate the role of the hearer in the construction and 
communication of impoliteness - something that has been somewhat lacking in approaches previous to that study ironically he risks doing so at the expense of the role of the speaker and the speaker's intent. He then further adds that because of this, Culpeper's (2005) definition of impoliteness is not one which could be considered to be always coconstructed by participants in interaction.

In line with this point, researchers such as Arundale (2006), Locher and Watts (2005), and Mills (2003, 2005), amongst others, argue for the necessity of a model of impoliteness which considers and accounts for the constructed nature of the phenomenon. This necessity seems to be in place and also important. When there is a model and framework explaining different aspects of impoliteness, its understanding and as a result, its teaching and learning will be more effective, practical and possible.

There have also been some studies on different forms of impoliteness. For example, Kienpointner (1997) in his study wrote on various types of rude utterance displaying impoliteness. Austin (1990) also discussed forms of impolite behavior in New Zealand. And, in a rarely quoted but fascinating article, Baumann (1981) examined what he called the 'rhetoric of impoliteness' among the early Quakers in America. All these three studies considered the variety in the forms of impoliteness which may take place in different contexts.

Spencer-Otay (2000) also offered a framework for various types of impoliteness. According to this framework, there are four types of impoliteness:

1. Individual impoliteness: impoliteness which the hearer perceives as a personal attack.

2. Social impoliteness: impoliteness which the hearer perceives as an attack on her/his social role.

3. Cultural impoliteness: impoliteness which the hearer perceives as an attack on her/his ethnic group.

4. Banter: impoliteness which reflects the playful use of impolite language.

Mugford (2008) asserts that the Spencer-Otay's taxonomy makes it possible to differentiate between impoliteness at a personal level (i.e. individual impoliteness) which may be unique and opportunistic to a given occasion and social and cultural impoliteness which may be more systematic and recurring. The inclusion of banter offers a light-hearted way of dealing with impoliteness and offers a linguistic resource which L2 speakers can employ to try to tone down perceived impoliteness. However, banter is a cooperative activity between speakers and hearers and, if not appreciated for what it is, it can be perceived as aggressive. He further adds that whether banter should be considered as one kind of impoliteness or not is a matter of controversy.

It has also been stated that lack of intimacy is a factor which some researchers claim that leads to impoliteness. However, this claim has been disapproved by some other researchers. For instance, Birchler et al. (1975) discovered that even in happy marriages, spouses were typically more hostile towards each other than strangers. In a familiar relationship one has more scope for impoliteness, because one may know which aspects of face are particularly sensitive to attack, and be able to better predict and/or cope with retaliation that may ensue. They, however, note that it is absurd to assume that the more intimate one becomes with someone, the more impoliteness one employs.

Concerning the role of impoliteness in social situations, the dynamics of social interaction allows speakers to resort to a variety of linguistic strategies which promote, maintain, or attack an addressee's face, i.e. " the positive social value a person effectively claims for himself” (Goffman, 1967, P. 5). In some cases, a speaker may even employ a communicative strategy that deliberately creates social conflict with the addressee, thus causing disharmony between the interlocutors. Limberg (2009) focused on one of these strategies, that is, verbal threats and stated that they can be used to coerce and manipulate the target into (not) doing something which s/he considers to have an unfavorable outcome. He also asserted that there are two aspects which are particularly important in order to consider threats as a form of impoliteness. Firstly, it is a type of behavior that is purposefully initiated regardless of any face concerns towards the target. It is thereby crucial that the threatener's goals are credibly communicated to the target (Bleyle, 1995) Secondly, even though the threat utterance is issued by one speaker, impoliteness/rudeness is interactively constructed by both parties in a particular situation (Benoit, 1983).

A question which may be raised here is, whether impoliteness and rudeness are similar. Culpeper (2005) maintains that for lay people these two terms seem to be identical and they use them interchangeably. However, there seems to be some differences between them. The term rudeness, he further illuminates, could be reserved for cases where the offence is unintentionally caused, whilst the term impoliteness could be used for cases where the offence is intentionally caused. It means that the perception of intention is a crucial factor in an evaluation of the distinction between impoliteness and rudeness.

Mugford (2008) also argued that the world of L2 is not always a polite and respectful one. L2 users must be prepared to be involved in impolite and rude, as well as congenial and social interactions. While the learners' language level will be of paramount importance, L2 students, at the very least, should be aware of impoliteness in the target language. In the classroom, teachers can discuss perceptions of impoliteness in terms of intentionality, speaker purpose, and level of aggressiveness. Mugford's statement can point to the significance of the present study.

\section{THE PURPOSE OF THE STUDY}

Despite the importance of the impoliteness aspect of language, few researches have dealt with it adequately. Lack of research on this issue is greatly felt especially in the Iranian EFL context. Hence, the purpose of this study is to investigate the perspectives of language learners, teachers, and specialists as to the impoliteness aspect of language and 
whether there should be some language teaching materials and courses to teach the impoliteness aspect of language with the intention of making language learners ready to cope with the impolite situations happening in the real language use. As such, the study tries to answer the following research question:

How do Iranian EFL learners, teachers, experts and non-Iranian experts view teaching impoliteness in language classes?

\section{METHOD}

\section{A. Participants}

Four groups of participants took part in the present study: EFL learners, EFL teachers, Iranian language experts, and non-Iranian language experts. Language learners as the first group of the study consisted of 110 Iranian EFL students, 47 males and 63 females, ranging from 18 to 25 in age. They were all undergraduate students (freshman, sophomore, junior, and senior) studying either English Language Translation or English Language Literature courses. They were selected from four state universities of Shiraz, Isfahan, Shahrekord and Ahwaz. Convenience sampling was used in selecting the participants; that is, participants were selected on the basis of their availability.

The second group of the participants included 70 Iranian EFL teachers, 23 males and 47 females, with the age range of 18-40. They all held MA degrees in English Language Teaching or were completing their MA degree in the abovementioned universities.

As for the third and fourth groups, both Iranian and non-Iranian experts were selected to present their perspectives on the issue under study. For the Iranian experts, two professors from Shiraz University, one from Ahwaz University, one from Isfahan University, and one from Shahrekord University were picked out. Purposive sampling was employed to select the experts for the study. The criterion for selecting these professors was their publication on discourse in general and on politeness and impoliteness in particular. So they were considered as experts in this issue. The reason why only 5 experts were selected was that first of all, the number of people who could be considered as experts in this issue was very low. Second, some of the experts could not take part in the study, as they were very busy with their academic life.

Regarding the non-Iranian experts, eight professors from different universities around the world were selected. Five were non-Iranian speakers of English and three were non-non-Iranians. Table 1 summarizes the characteristics of the participants. Here again, due to communication problems, some experts did not take part in the study. Some others were also quite busy and didn't have the time to take part in the study.

TABLE 1:

CHARACTERISTICS OF THE PARTICIPANTS OF THE STUDY

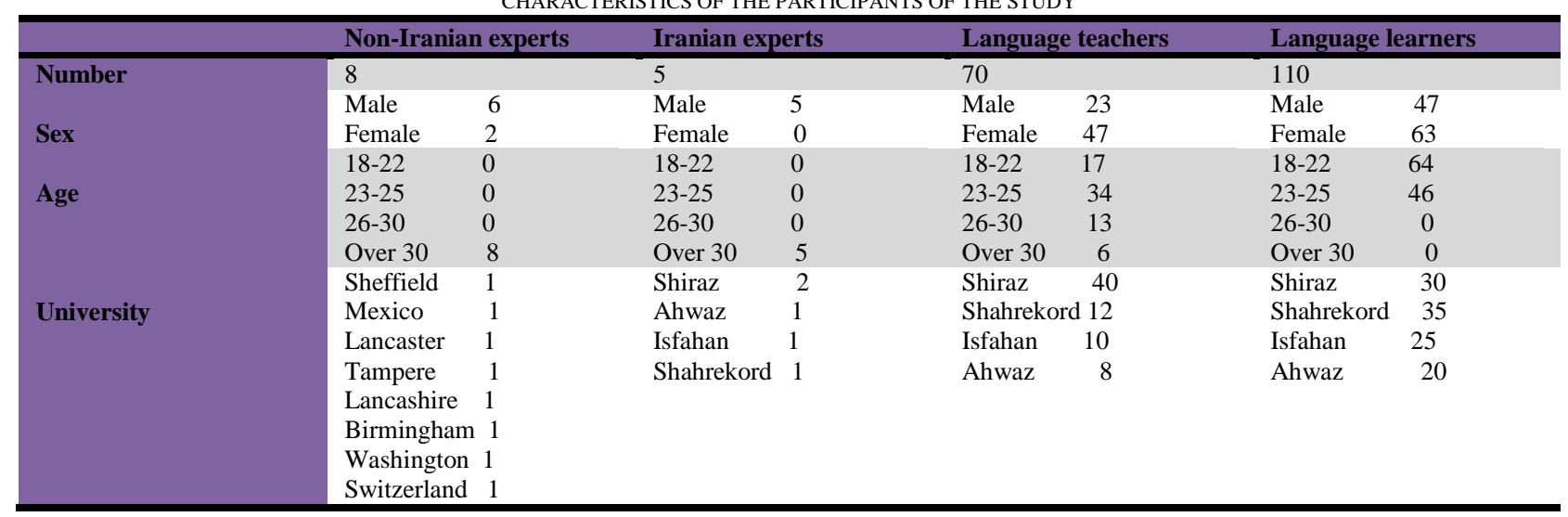

\section{B. Instruments}

In order to collect the data of the study, a Likert-format questionnaire was developed. It consisted of three parts; the first part was related to the demographic information of the participants. The second part incorporated 31 items on the impoliteness aspect of language. And the third part was a space provided for the participants to add any points about the issue if they wished.

To develop the questionnaire, scads of related books and papers were reviewed and some pertained experts and professors were consulted. The first draft of the questionnaire consisted of more than 40 items. However, after piloting the questionnaire and running factor analysis, it was reduced to 31 items. Of course, 2 filler items were also included to spot the respondents who provided unreal or by chance answers. Factor analysis confirmed the presence of seven factors in the questionnaire. The first factor including items 2, 8, and 19 was related to the significance of impoliteness in everyday use of language. The second factor, including items $11,14,24$, and 26, was related to the importance of impoliteness in contrast to politeness in general. The third factor was about the overall need for teaching impoliteness. It involved items $5,6,9,10,16,28$, and 31 . The forth factor, including items 21 , and 29 , pertained to the way the impoliteness aspect of language should be taught. The fifth factor, including items 1, 3, 4, 7, 12, 15, 18, 25, 27, and 30, 
was about the levels at which impoliteness should be taught. The sixth factor included items 17 and 23 and asked for the relationship between gender and impoliteness. And finally, the seventh factor which involved items 13, 20, and 22 addressed the context (EFL or ESL) in which impoliteness needs to be taught.

As for the reliability of the questionnaire, Cronbach Alpha was used and it turned out to be 00.68.

\section{Data Collection Procedure and Analysis}

The developed questionnaire was distributed among the selected participants. They were allowed to take the questionnaire home and give it back at their conveniences. The main reason for this was to make sure that they would have enough time thinking about the questions and providing real answers.

The data collected were analyzed using a One-way ANOVA to see whether different groups of participants had different ideas toward (the teaching of) impoliteness. In the next part the results are presented and discussed.

\section{RESULTS}

In this section the main findings of the study are presented and illuminated. Table 2 presents the descriptive statistics in this regard. This table provides us with the mean and standard deviation of the participants' responses to each of the factors (aspects of impoliteness).

TABLE 2.

DESCRIPTIVE STATISTICS OF DIFFERENT ASPECTS OF IMPOLITENESS

\begin{tabular}{|c|c|c|c|c|c|c|c|c|c|c|c|c|}
\hline \multirow[b]{3}{*}{ Factor 1} & \multicolumn{3}{|c|}{ Language learner } & \multicolumn{3}{|c|}{ Language teacher } & \multicolumn{3}{|c|}{ Non-Iranian expert } & \multicolumn{3}{|c|}{ Iranian expert } \\
\hline & Number & Mean & SD & Number & Mean & SD & Number & Mean & SD & Number & Mean & SD \\
\hline & 110 & 2.00 & .22 & 70 & 1.92 & .35 & 8 & 2.03 & .09 & 5 & 2.35 & .38 \\
\hline Factor 2 & 110 & 2.23 & .27 & 70 & 2.31 & .30 & 8 & 2.12 & .47 & 5 & 2.46 & .30 \\
\hline Factor 3 & 110 & 2.54 & .28 & 70 & 2.36 & .40 & 8 & 2.82 & .20 & 5 & 2.22 & .40 \\
\hline Factor 4 & 110 & 1.99 & .20 & 70 & 1.87 & .34 & 8 & 2 & .00 & 5 & 2.70 & .44 \\
\hline Factor 5 & 110 & 2.19 & .17 & 70 & 2.27 & .18 & 8 & 2.40 & .15 & 5 & 2.36 & .11 \\
\hline Factor 6 & 110 & 2.97 & .11 & 70 & 2.95 & .26 & 8 & 3 & .00 & 5 & 2.90 & .22 \\
\hline Factor 7 & 110 & 2.19 & .37 & 70 & 2.13 & .42 & 8 & 2.37 & .12 & 5 & 2.60 & .36 \\
\hline
\end{tabular}

The table depicts some noticeable differences among the means, meaning that the four groups had different ideas toward different aspects of impoliteness. However, to see whether these differences were significantly different, a series of one-way ANOVA was utilized. In what follows, the results of the study are presented for each of these factors separately.

\section{A. Factor One: The Significance of Impoliteness in Everyday Speech}

The first factor considered in the present study was the significance of the impoliteness aspect of language. Table 3 depicts significant differences among the groups as to their idea concerning this factor.

TABLE 3

ANOVA RESULTS FOR THE SIGNIFICANCE OF IMPOLITENESS

\begin{tabular}{|l|l|l|l|l|c|}
\hline & Sum of squares & df & Mean square & F & Sig. \\
\hline Between groups & 1.02 & 3 & .34 & 4.49 & .005 \\
\hline Within groups & 14.43 & 189 & .07 & & \\
\hline Total & 15.46 & 192 & & & \\
\hline
\end{tabular}

To see where the differences between groups exactly lay, a post-hoc test (Tucky test) was run (Table 4). It indicated that the significant differences existed only when language learners were compared with Iranian experts and also when language teachers were compared with Iranian experts.

TABLE 4

POST-HOC TEST (TUCKY) ON THE SIGNIFICANCE OF IMPOLITENESS

\begin{tabular}{|c|c|c|c|c|c|c|c|}
\hline \multirow[t]{14}{*}{ Dependent Variable } & \multirow{3}{*}{$\begin{array}{l}\text { (I) code } \\
\text { lg. } \mathrm{L}\end{array}$} & \multirow{3}{*}{$\begin{array}{l}(\mathrm{J}) \text { code } \\
\lg . \mathrm{T}\end{array}$} & \multirow{3}{*}{$\begin{array}{l}\text { Mean Difference (I-J) } \\
.087\end{array}$} & \multirow{3}{*}{$\begin{array}{l}\text { Std. Error } \\
.042\end{array}$} & \multirow{3}{*}{$\begin{array}{l}\text { Sig. } \\
.165\end{array}$} & \multicolumn{2}{|c|}{$95 \%$ Confidence Interval } \\
\hline & & & & & & Lower Bound & Upper Bound \\
\hline & & & & & & -.02 & .19 \\
\hline & & N.I.expert & -.022 & .101 & .996 & -.28 & .24 \\
\hline & & I.expert & $-.340^{*}$ & .126 & .038 & -.66 & -.01 \\
\hline & $\lg . \mathrm{T}$ & $\lg . \mathrm{L}$ & -.087 & .042 & .165 & -.19 & .02 \\
\hline & & N.I.expert & -.109 & .103 & .711 & -.37 & .15 \\
\hline & & I.expert & $-.428^{*}$ & .127 & .005 & -.76 & -.09 \\
\hline & N.I.expert & $\lg . \mathrm{L}$ & .022 & .101 & .996 & -.24 & .28 \\
\hline & & $\lg . \mathrm{T}$ & .109 & .103 & .711 & -.15 & .37 \\
\hline & & I.expert & -.318 & .157 & .183 & -.72 & .08 \\
\hline & I.expert & $\lg . \mathrm{L}$ & $.340^{*}$ & .126 & .038 & .01 & .66 \\
\hline & & $\lg . \mathrm{T}$ & $.428^{*}$ & .127 & .005 & .09 & .76 \\
\hline & & N.I.expert & .318 & .157 & .183 & -.08 & .72 \\
\hline
\end{tabular}

\section{B. Factor Two: The Value of Impoliteness as Compared to Politeness}


The second factor was pertaining to the value of impoliteness in comparison to politeness. As indicated in table 5, the one-way ANOVA result is not significant meaning that the participants were not at variance with each other concerning their idea toward this issue.

TABLE 5

ANOVA RESULTS FOR THE VALUE OF IMPOLITENESS AS COMPARED TO POLITENESS

\begin{tabular}{|l|l|l|l|l|l|}
\hline & Sum of squares & $\mathrm{df}$ & Mean square & $\mathrm{F}$ & Sig. \\
\hline Between groups & .63 & 3 & .21 & 2.45 & .06 \\
\hline Within groups & 16.24 & 189 & .08 & & \\
\hline Total & 16.87 & 192 & & & \\
\hline
\end{tabular}

\section{Factor Three: Does Impoliteness Require Instruction?}

The main point of the study was about teaching impoliteness; that is, whether impoliteness needs any instruction or not. Table 6 depicts the results of one-way ANOVA in this regard. It indicates that the differences are significant.

TABLE 6

ANOVA RESULTS FOR THE IMPOLITENESS INSTRUCTION

\begin{tabular}{|l|l|l|l|l|l|}
\hline & Sum of squares & df & Mean square & F & Sig. \\
\hline Between groups & 2.60 & 3 & .86 & 7.88 & .000 \\
\hline Within groups & 20.82 & 189 & .11 & & \\
\hline Total & 23.42 & 192 & & & \\
\hline
\end{tabular}

To see where exactly the differences among the four groups lay, a post hoc test (Tucky) was used. It indicated a significant difference when comparing language learners with language teachers, language teachers with non-Iranian experts, and also non-Iranian experts with Iranian experts.

TABLE 7

POST-HOC TEST (TUCKY) ON THE IMPOLITENESS INSTRUCTION

\begin{tabular}{|c|c|c|c|c|c|c|c|}
\hline \multirow[t]{2}{*}{ Dependent Variable } & \multirow[t]{2}{*}{ (I) code } & \multirow[t]{2}{*}{ (J) code } & \multirow[t]{2}{*}{ Mean Difference (I-J) } & \multirow[t]{2}{*}{ Std. Error } & \multirow[t]{2}{*}{ Sig. } & \multicolumn{2}{|c|}{$95 \%$ Confidence Interval } \\
\hline & & & & & & Lower Bound & Upper Bound \\
\hline & lg.L & lg.T & $.178^{*}$ & .050 & .003 & .04 & .30 \\
\hline & & N.I.expert & -.275 & .121 & .109 & -.59 & .03 \\
\hline & & I.expert & .316 & .151 & .161 & -.07 & .71 \\
\hline & $\lg . \mathrm{T}$ & $\lg . \mathrm{L}$ & $-.178^{*}$ & .050 & .003 & -.30 & -.04 \\
\hline & & N.I.expert & $-.454^{*}$ & .123 & .002 & -.77 & -.13 \\
\hline & & I.expert & .138 & .153 & .803 & -.25 & .53 \\
\hline & N.I.expert & $\lg . \mathrm{L}$ & .275 & .121 & .109 & -.03 & .59 \\
\hline & & lg.T & $.454^{*}$ & .123 & .002 & .13 & .77 \\
\hline & & I.expert & $.592^{*}$ & .189 & .011 & .10 & 1.08 \\
\hline & I.expert & $\lg . \mathrm{L}$ & -.316 & .151 & .161 & -.71 & .07 \\
\hline & & lg. $T$ & -.138 & .153 & .803 & -.53 & .25 \\
\hline & & N.I.expert & $-.592^{*}$ & .189 & .011 & -1.08 & -.10 \\
\hline
\end{tabular}

\section{Factor Four: Direct vs. Indirect Teaching of Impoliteness}

As to the way the impoliteness aspect of language should be taught (Table 8), a significant difference was found in the means of the groups of the study. In other words, their ideas on the way impoliteness should be taught were inconsistent with each other.

TABLE 8

ANOVA RESULTS FOR DIRECT VS INDIRECT TEACHING OF IMPOLITENESS

\begin{tabular}{|l|l|l|l|l|l|}
\hline & Sum of squares & df & Mean square & F & Sig. \\
\hline Between groups & 3.39 & 3 & 1.13 & 16.29 & .000 \\
\hline Within groups & 13.13 & 189 & .06 & & \\
\hline Total & 16.53 & 192 & & & \\
\hline
\end{tabular}

Tucky post hoc test indicated that except for the language learners vs non-Iranian experts, and language teachers vs non-Iranian experts comparisons, all the other comparisons depicted significant differences. 
TABLE 9

POST-HOC TEST (TUCKY) ON DIRECT VS INDIRECT TEACHING OF IMPOLITENESS

\begin{tabular}{|c|c|c|c|c|c|c|c|}
\hline \multirow[t]{14}{*}{ Dependent Variable } & \multirow{3}{*}{$\begin{array}{l}\text { (I) code } \\
\text { lg.L }\end{array}$} & \multirow{2}{*}{ (J) code } & \multirow{2}{*}{ Mean Difference (I-J) } & \multirow{2}{*}{ Std. Error } & \multirow[t]{2}{*}{ Sig. } & \multicolumn{2}{|c|}{ 95\% Confidence Interval } \\
\hline & & & & & & Lower Bound & Upper Bound \\
\hline & & $\lg . T$ & $.119^{*}$ & .04 & .01 & .01 & .22 \\
\hline & & N.I.expert & -.009 & .09 & 1.0 & -.25 & .24 \\
\hline & & I.expert & $-.709^{*}$ & .12 & .00 & -1.02 & -.39 \\
\hline & $\lg . T$ & lg.L & $-.119^{*}$ & .04 & .01 & -.22 & -.01 \\
\hline & & N.I.expert & -.128 & .09 & .56 & -.38 & .12 \\
\hline & & I.expert & $-.828^{*}$ & .12 & .000 & -1.14 & -.51 \\
\hline & N.I.expert & $\lg . \mathrm{L}$ & .009 & .09 & 1.00 & -.24 & .25 \\
\hline & & $\lg . T$ & .128 & .09 & .56 & -.12 & .38 \\
\hline & & I.expert & $-.700^{*}$ & .15 & .000 & -1.08 & -.31 \\
\hline & I.expert & lg.L & $.709^{*}$ & .120 & .000 & .39 & 1.02 \\
\hline & & $\lg . T$ & $.828^{*}$ & .122 & .000 & .51 & 1.14 \\
\hline & & N.I.expert & $.700^{*}$ & .150 & .000 & .31 & 1.08 \\
\hline
\end{tabular}

\section{E. Factor Five: The Level of Teaching Impoliteness}

Table 10 presents the results of the study for the fifth factor; that is, the level at which the impoliteness aspect of language should be taught. It is evident, based on the ANOVA results, that the groups are significantly different as to their idea concerning this factor.

TABLE 10

ANOVA RESULTS FOR THE LEVEL OF TEACHING IMPOLITENESS

\begin{tabular}{|l|l|l|l|l|c|}
\hline \multicolumn{1}{|c|}{ ANOVA RESULTS FOR THE LEVEL OF TEACHING IMPOLITENESS } \\
\hline Between groups & Sum of squares & df & Mean square & F & Sig. \\
\hline Within groups & 5.62 & 3 & .174 & 5.84 & .001 \\
\hline Total & 6.15 & 189 & .030 & & \\
\hline
\end{tabular}

To see where exactly the differences among the four groups lay, a post hoc test (Tucky) was used. Table 11 indicates the differences. As depicted, the significant differences were found in the following group comparisons: language learners vs. language teachers, and language learners vs. non-Iranian experts.

TABLE 11

POST-HOC TEST (TUCKY) ON THE LEVEL OF TEACHING IMPOLITENESS

\begin{tabular}{|c|c|c|c|c|c|c|c|}
\hline \multirow[t]{14}{*}{ Dependent Variable } & \multirow{3}{*}{$\begin{array}{l}\text { (I) code } \\
\lg . \mathrm{L}\end{array}$} & \multirow{3}{*}{$\begin{array}{l}\text { (J) code } \\
\lg . \mathrm{T}\end{array}$} & \multirow{3}{*}{$\begin{array}{l}\text { Mean Difference (I-J) } \\
-.070^{*}\end{array}$} & \multirow{3}{*}{$\begin{array}{l}\text { Std. Error } \\
.026\end{array}$} & \multirow{3}{*}{$\begin{array}{l}\text { Sig. } \\
.039\end{array}$} & \multicolumn{2}{|c|}{$95 \%$ Confidence Interval } \\
\hline & & & & & & Lower Bound & Upper Bound \\
\hline & & & & & & -.139 & -.002 \\
\hline & & N.I.expert & $-.200^{*}$ & .063 & .009 & -.364 & -.037 \\
\hline & & I.expert & -.160 & .078 & .177 & -.365 & .043 \\
\hline & $\lg . \mathrm{T}$ & $\lg . \mathrm{L}$ & $.070^{*}$ & .026 & .039 & .002 & .139 \\
\hline & & N.I.expert & -.130 & .064 & .185 & -.299 & .036 \\
\hline & & I.expert & -.090 & .079 & .674 & -.297 & .117 \\
\hline & N.I.expert & $\lg . \mathrm{L}$ & $.200^{*}$ & .063 & .009 & .037 & .364 \\
\hline & & $\lg . \mathrm{T}$ & .130 & .064 & .185 & -.036 & .296 \\
\hline & & I.expert & .040 & .098 & .977 & -.215 & .295 \\
\hline & I.expert & $\lg . \mathrm{L}$ & .160 & .078 & .177 & -.043 & .365 \\
\hline & & $\lg . \mathrm{T}$ & .090 & .079 & .674 & -.117 & .297 \\
\hline & & N.I.expert & -.040 & .098 & .977 & -.295 & .215 \\
\hline
\end{tabular}

\section{F. Factor Six: Teaching Impoliteness to Males or Females?}

The sixth factor considered in the study was the issue of gender and impoliteness; that is, whether there should be any difference in teaching the impoliteness aspect of language to different genders. The results of the one-way ANOVA indicated no significant difference in this regard. This means that the four groups held the same idea toward the relationship between gender and impoliteness; that males and females should be treated equally in (not) receiving instruction on impoliteness.

TABLE 12

ANOVA RESULTS FOR TEACHING IMPOLITENESS TO DIFFERENT GENDERS

\begin{tabular}{|l|l|l|l|l|l|}
\hline & Sum of squares & df & Mean square & F & Sig. \\
\hline Between groups & .63 & 3 & .21 & 2.45 & .06 \\
\hline Within groups & 16.26 & 189 & .08 & & \\
\hline Total & 16.87 & 192 & & & \\
\hline
\end{tabular}

\section{G. Factor Seven: Teaching Impoliteness in EFL and ESL Contexts}

The last factor of the study centered on the context in which impoliteness could be taught. The results of the one-way ANOVA indicated that the differences were not significant. Table 13 indicates that the significant value is .057 which is a bit larger than what it should be to indicate significance differences. This means that the four groups of the study had, 
more or less, similar ideas toward the context of teaching impoliteness. In fact, almost all the participants believed that if the impoliteness aspect of language is to be taught, then context does not make a big difference.

TABLE 13

ANOVA RESULTS FOR TEACHING IMPOLITENESS IN ESL/EFL CONTEXTS

\begin{tabular}{|l|l|l|l|l|l|}
\hline & Sum of squares & df & Mean square & F & Sig. \\
\hline Between groups & 1.30 & 3 & .43 & 2.89 & .057 \\
\hline Within groups & 28.39 & 189 & .15 & & \\
\hline Total & 29.70 & 192 & & & \\
\hline
\end{tabular}

\section{DISCUSSION}

Here in this part, the research question of the study is presented and discussed on the basis of the results of the study.

Research question: How do Iranian EFL learners, teachers, experts and non-Iranian experts view teaching impoliteness in language classes?

To answer this question, each of the factors is explained and discussed according to the ideas of the four groups of the participants.

\section{A. Factor One: The Significance of Impoliteness in Everyday Language}

Concerning the overall significance of impoliteness, almost all the four groups were of the idea that impoliteness is part of everyday use of language including the English language. This is consistent with what Mugford (2008) stated; that the world of every language is not always a polite and respectful one. Therefore, language learners must be prepared to be involved in impolite and rude, as well as congenial and social interactions. Despite this general trend toward the importance of impoliteness, the results of the one-way ANOVA indicated that there were some significant differences in their ideas toward this factor as well. The difference was between Iranian experts on the one hand and language learners and teachers on the other hand. Iranian experts were more explicit and consistent in their ideas toward the value of impoliteness, whereas some learners and teachers were more conservative in talking about the value of impoliteness and that was the cause of the significant difference found. Non-Iranian experts were middle of the roaders; not as explicit and consistent as Iranian experts and not as conservative and inconsistent as language learners and teachers on this issue.

\section{B. Factor Two: The Value of Impoliteness as Compared to Politeness}

As for the value of politeness in contrast to impoliteness, the study found no significant difference among the four groups. All the four groups almost unanimously agreed to the equal value of politeness and impoliteness.

\section{Factor Three: Does Impoliteness Require Instruction?}

The study indicated significant differences between the groups in terms of the need for instruction. The significant differences were found between language teachers on the one hand and language learners and Iranian experts on the other hand. There was also a significant difference between Iranian experts and non-Iranian experts. However, language learners and Iranian experts were not significantly different in their ideas about teaching impoliteness and similarly language teachers and non-Iranian experts were of similar ideas in this regard. Language teachers were mostly concerned with the class management. They mostly believed that any instruction of the impoliteness aspect of language may cause chaos and disorder in the class. Furthermore, they stated, it may not be ethically appropriate to teach impoliteness, and even if it is to be taught, just some certain aspects of it should be taught. Non-Iranian experts were of similar idea in this regard, but language learners were somehow diverse on this issue with some believing in instruction and some disagreeing to it. However, most of them believed that instruction is needed. Iranian experts had the same position in this regard, but they were more consistent in their idea about the need for instruction.

\section{Factor Four: Direct vs. Indirect Teaching of Impoliteness}

Concerning the method of teaching impoliteness, the results of the one-way ANOVA indicated significant differences among the groups. Iranian experts were significantly different from the other three groups. They were mostly of the idea that if impoliteness is to be taught, it should be taught explicitly and directly. Language teachers were also significantly different from the language learners, as teachers were basically against explicit or direct instruction, believing that it can create chaos in the class. Non-Iranian experts like language learners were overall neutral on this point with some agreeing to explicit instruction and some to implicit instruction.

\section{E. Factor Five: Level of Teaching Impoliteness}

Concerning the level of proficiency at which impoliteness should be taught, the results indicated significant differences only between language learners on the one hand and language teachers and non-Iranian experts on the other hand. In fact, all the groups believed that if impoliteness is to be taught, higher levels seem more suitable for teaching; that is, students of higher proficiency are better candidates to receive instruction. It seems that the significant differences found were basically related to the fact that language learners didn't believe in the idea of teaching 
impoliteness to intermediate and beginning level students, whereas some of the participants in other groups, especially the language teachers and non-Iranian experts, thought that if impoliteness is to be taught, it is better to be taught at different levels.

\section{F. Factor Six: Teaching Impoliteness to Males or Females?}

All the four groups of the study unanimously agreed to the fact that males and females should be treated equally in (not) teaching the impoliteness aspect of language. The results of the one-way ANOVA revealed no significant results in this regard.

\section{G. Factor Seven: Teaching Impoliteness in EFL and ESL Contexts}

As for the context in which impoliteness may require instruction, the study indicated no significant results among the different groups. Most of the participants regardless of their group membership believed that context is not a determining factor in deciding (not) to teach the impoliteness aspect of language.

\section{CONCLUSION}

The following conclusions can be drawn from the study:

Politeness and impoliteness are two aspects of any language which are used in every day speech depending on the context. In other words, they are context oriented. As such, it is a necessity for language learners to have knowledge and consciousness about these two aspects. Although raising students' consciousness about impoliteness aspect of language seems vital to successful communication, as stated by most of the participants, the way to raise this consciousness and the level of proficiency appropriate for consciousness raising are not agreed-upon by different groups of learners, teachers, Iranian experts and non-Iranian experts.

In an Iranian EFL context and due to the specific cultural and religious conditions, it may not be ethical and justifiable to teach the impoliteness aspect of the English language explicitly and directly and in case the rude side of the English language is to be directly taught, it should be done in higher levels of education. Therefore, it seems more ethically appropriate and easier for the Iranian EFL learners to become aware of the impoliteness aspect of the English language through implicit learning and self instruction.

\section{APPENDIX IMPOLITENESS QUESTIONNAIRE}

Dear participant:

Please read the following items and then mark the choice which best matches your perspective. Your answers are only used for research purposes and you will remain anonymous. In the end, the author expresses his heartfelt thanks to you for your honest and sincere cooperation.

Gender: $\quad$ Male $\bigcirc$ Female $\bigcirc$

Education level: Freshman $\bigcirc$ Sophomore $\bigcirc$ Junior $\bigcirc$ Senior $\bigcirc$ M.A. $\bigcirc$

Age:

The questions have a five-point answering scale. The numbers mean:
Strongly agree
Agree
(2)
Disagree
(4)
Strongly disagree
(5)

\begin{tabular}{|c|c|c|c|c|c|c|}
\hline 1 & Impoliteness aspect of language should be taught in all levels. & 1 & 2 & 3 & 4 & 5 \\
\hline 2 & Impoliteness aspect of language has the same significance as the politeness aspect. & 1 & 2 & 3 & 4 & 5 \\
\hline 3 & Impoliteness aspect of language should be taught just in high levels. & 1 & 2 & 3 & 4 & 5 \\
\hline 4 & Impoliteness should be taught just in universities. & 1 & 2 & 3 & 4 & 5 \\
\hline 5 & Language learners themselves should learn about the impoliteness aspect of language. & 1 & 2 & 3 & 4 & 5 \\
\hline 6 & Teaching the impoliteness aspect of language or not, makes no difference in learning that language. & 1 & 2 & 3 & 4 & 5 \\
\hline 7 & $\begin{array}{l}\text { Both politeness and impoliteness aspects of language should be taught. But the main focus should be on the } \\
\text { politeness aspect. }\end{array}$ & 1 & 2 & 3 & 4 & 5 \\
\hline 8 & Politeness aspect of language is more important than the impoliteness aspect. & 1 & 2 & 3 & 4 & 5 \\
\hline 9 & Teachers should not waste class time by dealing with the impoliteness aspect of language. & 1 & 2 & 3 & 4 & 5 \\
\hline 10 & Teaching the impoliteness aspect of language will disrupt the order of class. & 1 & 2 & 3 & 4 & 5 \\
\hline 11 & In being able to communicate in a foreign language just learning the politeness aspect of that language suffice. & 1 & 2 & 3 & 4 & 5 \\
\hline 12 & Impoliteness aspect of language should be taught just in intermediate levels. & 1 & 2 & 3 & 4 & 5 \\
\hline 13 & $\begin{array}{l}\text { In foreign language contexts, there is no need to teach impoliteness aspect of language, but in second language } \\
\text { contexts, it is a necessity. }\end{array}$ & 1 & 2 & 3 & 4 & 5 \\
\hline 14 & Impoliteness aspect of language has not much application in communication. & 1 & 2 & 3 & 4 & 5 \\
\hline 15 & Teachers should be trained to teach and offer strategies to students for dealing with L2 impoliteness. & 1 & 2 & 3 & 4 & 5 \\
\hline 16 & There is no need to teach impoliteness aspect of language. & 1 & 2 & 3 & 4 & 5 \\
\hline 17 & Impoliteness aspect of language should be taught Just to the male language learners. & 1 & 2 & 3 & 4 & 5 \\
\hline 18 & Impoliteness aspect of language should be taught just in beginning levels. & 1 & 2 & 3 & 4 & 5 \\
\hline 19 & Impoliteness aspect of language is more important than politeness aspect. & 1 & 2 & 3 & 4 & 5 \\
\hline 20 & $\begin{array}{l}\text { In Second language contexts, there is no need to teach impoliteness aspect of language, but in Foreign language } \\
\text { contexts, it is a necessity. }\end{array}$ & 1 & 2 & 3 & 4 & 5 \\
\hline
\end{tabular}




\begin{tabular}{|c|c|c|c|c|c|c|}
\hline 21 & Impoliteness aspect of language should be taught directly. & 1 & 2 & 3 & 4 & 5 \\
\hline 22 & In both foreign and second language contexts, the impoliteness aspect of language should be taught. & 1 & 2 & 3 & 4 & 5 \\
\hline 23 & Impoliteness aspect of language should be taught Just to the female language learners. & 1 & 2 & 3 & 4 & 5 \\
\hline 24 & Impoliteness is part of daily language use and language learners need to be prepared to cope with these situations. & 1 & 2 & 3 & 4 & 5 \\
\hline 25 & $\begin{array}{l}\text { Both politeness and impoliteness aspects of language should be taught. But the main focus should be on the } \\
\text { impoliteness aspect. }\end{array}$ & 1 & 2 & 3 & 4 & 5 \\
\hline 26 & True and real communication in any language involves using both politeness and impoliteness strategies. & 1 & 2 & 3 & 4 & 5 \\
\hline 27 & Impoliteness aspect of language should be taught just in Secondary schools. & 1 & 2 & 3 & 4 & 5 \\
\hline 28 & Teaching the impoliteness aspect of language is not in agreement with our cultural norms. & 1 & 2 & 3 & 4 & 5 \\
\hline 29 & Impoliteness should be taught indirectly. & 1 & 2 & 3 & 4 & 5 \\
\hline 30 & Impoliteness should be taught since the early stages of language learning in elementary schools. & 1 & 2 & 3 & 4 & 5 \\
\hline 31 & It depends on teachers' view to teach impoliteness aspect of language or not. & 1 & 2 & 3 & 4 & 5 \\
\hline
\end{tabular}

\section{REFERENCES}

[1] Arundale, R. (2006). Face as relational and interactional: A communication framework for research on face, face work, and politeness. Journal of Politeness Research, 2 (2), 193-217.

[2] Austin, P. (1990). Politeness revisited: the dark side. In A. Bell, and J. Holmes, (Eds.), New Zealand ways of speaking English (pp. 277-93). Clevedon: Multilingual Matters.

[3] Bauman, R. (1981). Christ respects no man's person: the plain language of the early quakers and the rhetoric of impoliteness. Sociolinguistic Working Paper 88, University of Texas, Austin, TX.

[4] Beebe, L. M. (1995). Polite fictions: instrumental rudeness as pragmatic competence. In J. E. Alatis, C. A. Straehle, B. Gallenberger, \& M. Ronkin (Eds.),: Linguistics and the education of language teachers: Ethnolinguistic, psycholinguistics and sociolinguistic aspects (PP. 379-397), Washington, DC: Georgetown University Press.

[5] Birchler, G., Weiss, R., \& Vincent, J. (1975). Multi-method analysis of social reinforcement exchange between maritally distressed and non-distressed spouse and stranger dyads. Journal of Personality and Social Psychology, 31, 349-360.

[6] Bousfield, D. (2007). Beginnings, middles and ends: A biopsy of the dynamics of impolite exchanges. Journal of Pragmatics, 39 (12), 2185-2216.

[7] Bousfield, D. (2008). Impoliteness in the struggle for power. In D. Bousfield, \& M.A. Locher, (Eds.). Impoliteness in language: Studies on its interplay with power in theory and practice (pp. 127-154), Berlin: Mouton de Gruyter.

[8] Culpeper, J. (2005). Impoliteness and entertainment in the television quiz show: the Weakest link. Journal of Politeness Research, 1, 35-72.

[9] Culpeper, J., Bousfield, D., \& Wichmann, A. (2003). Impoliteness revisited: With special reference to dynamic and prosodic aspects. Journal of Pragmatics, 35, 1545-1579.

[10] Goffman, E. (1967). Interaction ritual: Essays on face to face behavior. Bantam Books, Garden City: New York.

[11] Kienpointner, M. (1997). Varieties of rudeness: types and functions of impolite utterances. Functions of Language 4(2), $251-87$.

[12] Lakoff, R. (1989). The limits of politeness: therapeutic and courtroom discourse. Multilingual, 8, 101-129.

[13] Leech, G. (1983). Principles of Pragmatics. London: Longman.

[14] Limberg, H. (2009). Impoliteness and threat responses. Journal of Pragmatics, 41, 1376-1394.

[15] Locher, M. \& Watts, R. (2005). Politeness theory and relational work. Journal of Politeness Research 1 (1), 9-33.

[16] Mills, S. (2003). Gender and politeness. Cambridge: Cambridge University Press.

[17] Mills, S. (2005). Gender and impoliteness. Journal of Politeness Research, 1 (2), 263-280.

[18] Mugford, G. (2008). How rude! Teaching impoliteness in the second language classroom. ELT Journal, 62 (2), $375-379$.

[19] Spencer-Oatey, H. (2000). Culturally speaking: Managing rapport through talk across cultures. London: Continuum.

[20] Tracy, K. \& Tracy, S. J. (1998). Rudeness at 911: reconceptualizing face and face attack. Human Communication Research, 25, 225-251.

Alireza Ahmadi received his Ph.D. in TEFL from the University of Isfahan in 2008, his MA in TEFL from Shiraz University in 2002 and his BA in English Translation from the University of Allameh Tabatabaei in 2000.

Currently, he is an assistant professor in the Department of Foreign Languages and Linguistics at Shiraz University, Iran. His main interests include Language Assessment and Second Language Acquisition.

Kamal Heydari Soureshjani received his MA in TEFL from Shiraz University, in 2010 and his BA in English Translation from the University of Shahrekord in 2008.

$\mathrm{He}$ is a member of Young Researchers Club at Azad University, Shahrekord Branch, Iran. 